\title{
ANALISIS PENERAPAN TARIF PERDA NO 3 TAHUN 2011 ATAS RETRIBUSI PELAYANAN PERSAMPAHAN/KEBERSIHAN PADA MASYARAKAT KECAMATAN MALALAYANG DAN KECAMATAN SARIO KOTA MANADO
}

\author{
Pamela Firginia Jiaw ${ }^{1}$, Harijanto Sabijono ${ }^{2}$, Anneke Wangkar ${ }^{3}$ \\ 1,2,3 Jurusan Akuntansi, Fakultas Ekonomi dan Bisnis, Universitas Sam Ratulangi, Jl. Kampus Bahu, Manado, \\ 95115, Indonesia \\ E-mail : fangfangmey@gmail.com
}

\begin{abstract}
Retribution constituting regional levies on payment of services given by the government which one of it is general service levy which contains levy waste or hygiene. This study aims to (1) analyze implementation of tariff policy Levy Waste or Hygiene based on regional regulations Law Number (No.) 3 of 2011; (2) analyze tariff capability to covering operational costs of Levy Waste or Hygiene. The method used in this research is descriptive method. This study use the qualitative approach. The results shows, tariff policy Levy Waste or Hygiene implemented by Malalayang subdistrict and Sario subdistrict has been carried out in accordance with regional regulations Law Number (No.) 3 of 2011 and Levy Waste or Hygiene' tariff incompetent yet of covering operational costs thoroughly. The Local Government should re-collect data to compulsory levy whose unreached yet as of be able to increasing revenue in additional to cover the operational costs.

Keywords: Policy, Tariff, Regional Reglations, Levy Waste or Hygiene, Capability, Operational Costs
\end{abstract}

\section{PENDAHULUAN}

Pesatnya perkembangan zaman membuat persaingan global dalam menyelenggarakan pembangunan guna meningkatkan taraf dan kelangsungan hidup di setiap negara begitu terlihat jelas akhir-akhir ini. Indonesia merupakan salah satu dari sekian banyaknya negara yang mencoba memajukan wilayahnya dengan melakukan banyak inovasi dan pembangunan daerah. Dalam peningkatan tersebut, pembangunan daerah tentu harus berbanding lurus dengan penerimaan negara, salah satunya yaitu Pendapatan Asli Daerah (PAD).

Demi terlaksananya pelaksanaan dalam kaitannya dengan pembangunan dan penyelenggaraan suatu kegiatan pemerintahan, maka pemda harus melakukan peningkatkan Pendapatan Asli Daerah dimana salah satunya dari retribusi tiap-tiap daerah. Retribusi menurut UU Nomor 28 Tahun 2009 adalah pungutan yang berasal dari daerah yang khusus disediakan dan/atau diberikan oleh Pemerintah Daerah untuk kepentingan pribadi atau badan sebagai timbal balik pembayaran/pemberian atas jasa dan izin yang terkait.

Yang menjadi contoh dari retribusi jasa umum salah satunya adalah Retribusi Pelayanan Persampahan/kebersihan. Retribusi pada dasarnya berkaitan dengan kembalinya kontraprestasi (hubungan timbal balik) secara langsung oleh pemerintah. Demi terciptanya kebersihan dan keindahan kota khususnya Kota Manado untuk memenuhi segala tuntutan kebutuhan dan juga aspirasi dari masyarakat, oleh karena itu diperlukan adanya dukungan sarana dan prasarana dari pelayanan persampahan/kebersihan yang efisien. Dalam hal mengenai Retribusi Pelayanan Persampahan/Kebersihan, Dinas Pendapatan Daerah Kota Manado bertugas dalam membantu melaksanakan penyusunan dan pelaksanaan kebijakan daerah serta penerimaan pendapatan daerah di bidang pengelolaan pajak dan retribusi daerah.

Di Kota Manado sendiri total terdapat 9 Kecamatan dan 88 Kelurahan yang termasuk dalam pajak dan retribusi daerah dalam Dinas Pendapatan Kota Manado. Dalam Kecamatan 
Malalayang sendiri terdapat 9 kelurahan dan Kecamatan Sario terdapat 7 kelurahan yang diantaranya ada yang mendapat karcis retribusi karena di kelurahan mereka telah diterapkan sistem pemungutan pelayanan kebersihan dengan gerobak motor namun ada yang tidak mendapat karcis karena sebagian dari mereka telah membayar langsung kepada kepala lingkungan dan sebagian dari mereka belum diterapkannya sistem pemungutan pelayanan kebersihan dengan gerobak motor.

Peraturan daerah ini dibuat untuk menyokong biaya operasional dan menyesuaikan dengan tata cara hidup masyarakat kini. Tentunya Pemerintah melakukan pembaruan dengan mempertimbangkan hal-hal seperti mampu atau tidaknya masyarakat dalam membayar dan efektif atau tidaknya program baru tersebut terutama dalam pembiayaan operasionalnya sendiri.

\section{TINJAUAN PUSTAKA}

\subsection{Akuntansi Perpajakan}

Akuntansi Pajak adalah penerapan akuntansi yang bertujuan untuk menghitung besarnya pajak yang terutang. Fungsi dari akuntansi pajak umumnya mengolah dan menghitung data berupa informasi kuantitatif yang sudah tersedia serta berguna dalam penyajian pelaporan yaitu laporan keuangan yang didalamnya berisi perhitungan pajak seperti pajak yang terutang.

\subsection{Pengertian Pajak}

Dalam asas UU KUP Nomor 28 Tahun 2007 Pasal 1 angka 1 atas Ketentuan Umum Tata Cara Perpajakan, disebutkan bahwa pajak adalah kontribusi wajib kepada negara yang terutang oleh orang pribadi atau badan yang bersifat memaksa berdasarkan Undang-undang, dengan tidak mendapatkan imbalan secara langsung dan digunakan untuk keperluan negara bagi sebesar-besarnya kemakmuran rakyat.

\subsection{Pengertian Retribusi}

Menurut Pasal 1 ayat (64) UU No. 28 Tahun 2009 Retribusi Daerah yang selanjutnya disebut Retribusi adalah pungutan daerah sebagai pembayaran atas jasa atau pemberian izin tertentu yang khusus disediakan dan/atau diberikan oleh pemerintah daerah untuk kepentingan orang pribadi atau badan.

\subsubsection{Objek Retribusi Daerah}

Menurut Perundang-undangan No. 28 Tahun 2009 atas Pajak Daerah dan Retribusi Daerah dalam Marihot P. Siahaan (2013:619) yang menurutnya objek retribusi terbagi menjadi tiga bagian jasa, yaitu:

1. Retribusi Jasa Umum

a. Retribusi Pelayanan Kesehatan.

b. Retribusi Pelayanan Persampahan/Kebersihan.

c. Retribusi Penggantian Biaya Cetak Kartu Tanda Penduduk dan Akta Catatan Sipil.

d. Retribusi Pelayanan Pemakaman dan Pengabuan Mayat.

e. Retribusi Pelayanan Parkir di Tepi Jalan Umum.

f. Retribusi Pelayanan Pasar.

g. Retribusi Pengujian Kendaraan Bermotor.

h. Retribusi Pemeriksaan Alat Pemadam Kebakaran.

i. Retribusi Penggantian Biaya Cetak Peta.

j. Retribusi Penyediaan dan/atau Penyedotan Kakus.

k. Retribusi Pengolahan Limbah Cair.

1. Retribusi Pelayanan Tera/Tera Ulang.

m. Retribusi Pelayanan Pendidikan.

n. Retribusi Pengendalian Menara Telekomunikasi. 
2. Retribusi Jasa Usaha

a. Retribusi Pemakaian Kekayaan Daerah.

b. Retribusi Pasar Grosir Dan/Atau Pertokoan.

c. Retribusi Tempat Pelelangan.

d. Retribusi Terminal.

e. Retribusi Tempat Khusus Parkir.

f. Rertibusi Tempat Penginapan/Pesanggrahan/Villa.

g. Retribusi Rumah Potong Hewan

h. Retribusi Pelayanan Kepelabuhanan

i. Retribusi Tempat Rekreasi Dan Olahraga.

j. Retribusi Penyeberangan Air.

k. Retribusi Penjualan Produksi Usaha Daerah.

3. Retribusi Perizinan Tertentu

a. Retribusi Izin Mendirikan Bangunan.

b. Retribusi Izin Tempat Penjualan Minuman Beralkohol.

c. Retribusi Izin Gangguan.

d. Retribusi Izin Trayek.

e. Retribusi Izin Usaha Perikanan

\subsubsection{Prinsip dan Sasaran Tarif Retribusi}

Berdasarkan dengan isi Undang - Undang No 28 Tahun 2009 Pasal 149 ayat 2-4, dimana sesuai kewenangan masing-masing dari tiap daerah telah ditetapkan macam-macam retribusi yaitu jasa retribusi umum juga perizinan - perizinan tertentu untuk daerah bagian provinsi, kabupaten maupun kota. Begitu juga penetapan yang berlaku dalam macam-macam retribusi baik jasa retribusi dalam bentuk usaha untuk daerah provinsi dan kabupaten maupun kota, haruslah sejalan dengan baik jasa ataupun pelayanan yang diarahkan oleh pemerintah dari setiap daerah. Penyusunan jenis - jenis objek dari retribusi baik itu jasa umum, jasa usaha, serta perizinan tertentu diatur sesuai dengan perda yang terkait. (Siahaan 2013:621).

\subsection{Retribusi Pelayanan Persampahan/Kebersihan}

Berdasarkan Perda No 3 Tahun 2011, Retribusi Pelayanan Persampahan/kebersihan, yang selanjutnya disebut retribusi adalah pembayaran atas jasa penyelenggaraan pelayanan persampahan/kebersihan. Retribusi kebersihan adalah iuran atau pemungutan yang dikenakan pada pemakai jasa kebersihan yang dipungut berdasarkan undang-undang yang dapat pula dipaksakan dengan memperoleh imbalan yang memperoleh imbalan yang dapat dinikmati secara langsung. (Zurahniyah, 2015:4)

\subsection{Subjek dan Objek Retribusi Pelayanan Persampahan}

Menurut ketentuan yang diatur pada Perda No 3 Tahun 2011, Subjek yang termasuk pada Retribusi ini yaitu orang pribadi dan badan (organisasi atau instansi) dalam pemanfaatan fasilitas jasa yaitu Pelayanan Persampahan dan Kebersihan. Sedangkan yang termasuk Objek dalam Retribusi Jasa Umum yaitu pelayanan yang disediakan oleh Pemda demi tercapainya kepentingan umum serta dapat dinikmati baik orang pribadi atau badan. Retribusi Pelayanan Persampahan/Kebersihan berisi kegiatan pengambilan sampah dari rumah ke rumah, pengangkutan sampah dari rumah ke rumah, dan pembuangan dan pemusnahan sampah rumah tangga ke TPS kemudian ke TPA, dan perdagangan, tidak termasuk pelayanan kebersihan jalan - jalan umum dan taman.

\subsection{Tarif Retribusi Pelayanan Persampahan /Kebersihan}

Dalam penentuan tarif prinsip dan sasaran untuk penetapan struktur besarnya tarif retribusi berfungsi untuk menutup biaya penyelenggaraan atau operasional, pelayanan jasa dari melihat kemampuan wajib retribusi serta dari aspek keadilan, dasar dari adanya penetapan struktur besarnya tarif retribusi yaitu ditimbang dari segi pelayanan, jenis sampah dan volume dari sampah tersebut serta kemampuan wajib retribusi tersebut. Penetapan 
besarnya tarif retribusi pelayanan persampahan/kebersihan disusun dan diperhitungkan berdasarkan beban pekerjaan untuk menutupi pembiayaan penyelenggaraan pengelolaan persampahan dan pemeliharaan kebersihan.

Pembiayaan penyelenggaraan pengelolaan persampahan dan pemeliharaan kebersihan sebagaimana dimaksud pada ayat (1) adalah untuk pengangkutan sampah dari TPS ke TPA, pemeliharaan kebersihan tempat-tempat umum, jalan-jalan protokol, lapangan, pelataran umum, daerah aliran sungai,pesisir pantai, penyiapan armada angkutan, perbengkelan, pembelian suku cadang alat-alat berat, gerobak sampah, TPA, TPA, incenerator pembayaran gaji/upah buruh, biaya operasional/insentif bagi petugas.

\subsection{Biaya Operasional Sebagai Pemanfaatan Retribusi}

Biaya Operasional berfungsi untuk mendanai kegiatan - kegiatan dalam hal penyelenggaraan jasa yang saling berkaitan dan berhubungan (biaya operasional) yang berasal dari pendanaan tiap-tiap retribusi. Ketetapan dalam pemanfaatan penerimaan suatu retribusi telah diatur sesuai dengan perda.

\section{METODE PENELITIAN}

\subsection{Jenis Penelitian}

Penelitian ini termasuk dalam penelitian Kualitatif dengan analisis deskriptif dan cenderung menggunakan analisis. Penelitian kualitatif merupakan penelitian sosial dimana dalam meneliti menggunakan informasi-informasi terkait dan saling berhubungan dalam menginterpretasikan hasil.

\subsection{Tempat dan Waktu Penelitian}

Lokasi penelitian bertempat di Kantor Camat Malalayang dengan alamat Jl. Mogandi Kelurahan Malalayang Satu dan Kantor Camat Sario dengan alamat Jl. Ahmad Yani No. 49, Sario Utara, Sario, Kota Manado. Waktu pelaksanaan penelitian dimulai pada bulan April sampai dengan Juni.

\subsection{Jenis, Sumber dan Metode Pengumpulan data}

\subsubsection{Jenis Data}

Berdasarkan penelitian kali ini penulis menggunakan jenis data yaitu data kualitatif dan kuantitatif. Data kualitatif seperti wawancara mengenai penerapan tarif perda No 3 Tahun 2011 dan data kuantitatif seperti struktur besarnya klasifikasi tarif per rumah Wajib Retribusi.

\subsubsection{Sumber Data}

Data utama/ primer dalam penelitian ini yaitu data berdasarkan survei dan observasi lapangan secara langsung yaitu wawancara dengan masyarakat dan perangkat kecamatan baik di Kecamatan Malalayang dan Kecamatan Sario, sedangkan Data kedua/sekunder berupa data yang diperoleh atau yang telah disaring oleh lembaga pengumpul data serta telah dipublikasikan kepada masyarakat pengguna data seperti data yang didapat dari Pemerintah Kota Manado yaitu data klasifikasi struktur tarif Perda No 3 Tahun 2011.

\subsection{Metode Pengumpulan data}

1. Teknik Wawancara

Di sini, peneliti melakukan wawancara terhadap Aparat setempat seperti Kepala Lingkungan, Camat atau mereka yang bertugas di Kantor Kecamatan serta mereka yang terlibat langsung dengan Kegiatan Operasi Penerapan sistem pemungutan sampah dari rumah ke rumah juga masyarakat sekitar yang tinggal di Kecamatan Malalayang dan Kecamatan Sario yang dianggap dapat memberikan informasi yang dibutuhkan.

2. Teknik Dokumentasi

Dokumen dalam penelitian ini berisi tentang daftar responden penelitian, bukti karcis retribusi pelayanan persampahan/kebersihan, foto proses pengangkutan sampah dari rumah ke rumah, foto contoh penyetoran dan pencatatan iuran retribusi pelayanan 


\section{persampahan/kebersihan. \\ 3.5. Metode Analisis}

Analisis data disebut juga dengan pengolahan dan penafsiran data. Analisis data penulis dimulai dari meneliti data yang peneliti peroleh dari lapangan yaitu Peraturan Daerah No 3 Tahun 2011 yaitu yang berkaitan dengan Retribusi Pelayanan Persampahan/Kebersihan dimana ternyata klasifikasi struktur dan tarif yang ditetapkan berbeda dengan yang diterapkan pada masyarakat (Wajib Retribusi) yang disebut dengan mereduksi data. Kemudian penulis menyajikan data yang ada seperti ketidakselarasan antara tarif dalam Perda dan yang dipungut pemerintah setempat. Langkah berikutnya, ditarik kesimpulan awal yang masih bersifat sementara. Dalam hal ini, penulis menarik kesimpulan dalam masalah ini yaitu disebabkan karena kurangnya pengendalian dan pengawasan baik dalam pengangkutan sampah sampai pada pemungutan tarif iuran Retribusi Pelayanan Persampahan/Kebersihan terhadap Wajib Retribusi.

\section{HASIL PENELITIAN DAN PEMBAHASAN}

\subsection{Hasil Penelitian}

\subsubsection{Retribusi Pelayanan Persampahan pada Kecamatan Malalayang}

Kecamatan Malalayang dengan 9 kelurahan semuanya telah menerapkan tarif Perda

No 3 Tahun 2011 namun tidak sedikit dari masyarakat yang tidak tersentuh sampahnya tidak diangkut baik oleh motor maupun oleh truk sampah dan kebanyakan dari masyarakat tersebut tempat tinggalnya berlokasi di dalam gang-gang sempit/kecil. Banyak juga masyarakat yang tidak mendapat bukti karcis walaupun telah membayara iuran retribusi persampahan. Begitu juga dengan prosedur pemungutan iuran retribusi yang tidak merata. Ada beberapa kelurahan yang sistem pemungutan serta pembayarannya dikumpulkan dahulu kepada kepala lingkungan dan bukti dari pembayaran iuran retribusi persampahan ada yang dibuat dan dicatat dari kepala lingkungan, ada yang memang mendapat karcis retribusi.

\subsubsection{Retribusi Pelayanan Persampahan pada Kecamatan Sario}

Untuk kecamatan Sario dengan 7 kelurahan semuanya telah menerapkan tarif perda no 3 tahun 2011 namun didapati ada keluarga yang tidak mendapat karcis bahkan rumahnya yang menurut Perda no 3 tahun 2011 termasuk dalam golongan rumah permanen yang tidak bertingkat dikenai iuran retribusi persampahan/kebersihan sebesar Rp.20.000,00 dalam observasi dan wawancara penulis, masyarakat tersebut dikenakan iuran retribusi persampahan/kebersihan sebesar Rp.25.000,00. Ada masyarakat yang mendapat bukti hanya dalam bentuk kertas bukan karcis resmi dari pemerintah setempat. Banyak didapati petugaspetugas yang meminta iuran tiap hari dan iuran tiap bulan juga. Bahkan petugas pengangkut sampah beberapa kali tidak melewati jalur rumah yang sebenarnya merupakan jalurnya. Padahal sampah di rumah masyarakat sudah lama tertumpuk. Akibatnya beberapa masyarakat yang hanya mengolah sampahnya sendiri.

\subsection{Pembahasan}

\subsubsection{Retribusi Pelayanan Persampahan/Kebersihan pada Kecamatan Malalayang dan Kecamatan Sario}

Retribusi Pelayanan Persampahan/Kebersihan (RPPK) pada Kecamatan Malalayang dan Kecamatan Sario telah dilaksanakan sesuai Peraturan Daerah No.3 Tahun 2011 Retribusi Jasa Umum. Dalam besarnya tarif yang ditetapkan di masyarakat sesuai dengan Struktur Tarif dalam Peraturan Daerah No 3 Tahun 2011 dimana tarif berbeda-beda tiap rumah berdasarkan klasifikasi dan fungsi dari rumah tersebut. Hal ini dapat dilihat dari karcis yang diberikan per rumah sebagai tanda bukti pembayaran iuran retribusi pelayanan persampahan/kebersihan. Didalam karcis telah tertera besarnya iuran tarif yang harus dibayar per rumah atas retribusi persampahan yang dirasakan langsung oleh masyarakat/rumah tersebut. 
Dalam penjemputan dan pengangkutan sampah dari rumah ke rumah dilakukan oleh Petugas kebersihan yang disebut Tenaga Harian Lepas (THL) petugas sampah yang termasuk penyapu, pengangkut, dan pengawas dengan menggunakan truk sampah dan gerobak motor sampah untuk kemudian diangkut ke Tempat Pembuangan Sementara (TPS) disana kemudian dibawa ke Tempat Pembuangan Akhir (TPA). Dalam penagihan tarif iuran retribusi pelayanan persampahan/kebersihan dilakukan oleh petugas penagih yang dikhususkan untuk menagih per rumah. Rumah atau Wajib Retribusi yang sudah membayar kemudian diberikan karcis retribusi sebagai tanda bukti telah dipungutnya iuran retribusi pelayanan persampahan/kebersihan.

Penerapan Tarif RPP/K di Kecamatan Malalayang telah mengikuti Tarif yang dikeluarkan Pemerintah yang tercantum dalam Peraturan Daerah No 3 Tahun 2011 walaupun dalam masyarakat ada beberapa kelemahan seperti ada sampah dari rumah ke rumah masyarakat yang tidak diangkut yang mengakibatkan warga hanya mengolah sendiri sampah rumah tangga mereka dan berdampak pada kurangnya pendapatan yang dihasilkan dari pemungutan iuran retribusi ini.Masyarakat tentunya tidak akan membayar jika mereka tahu, pemerintah tidak ada langkah maju untuk menyetarakan ini.

Harusnya setiap sampah di rumah-rumah baik itu di gang kecil maupun di jalan besar dapat terorganisir dengan baik. Itu disebabkan karena penerapan tarif Perda khususnya $\mathrm{RPP} / \mathrm{K}$ kurang terorganisir dengan baik. Dapat dilakukan penyisiran kembali setelah pengangkutan sampah dari rumah ke rumah. Penerapan tarif RPP/K di Kecamatan Sario telah mengikuti tarif yang dikeluarkan pemerintah yang tercantum dalam Peraturan Daerah No 3 Tahun 2011. Walaupun dalam masyarakat ada beberapa kelemahan seperti rumah Wajib Retribusi yang dikenai biaya iuran lebih tinggi dari klasifikasi, struktur, dan besar tarif yang dikenakannya. Ada juga masyarakat yang membayar tiap bulan namun tidak pernah mendapat karcis tanda bukti pembayaran RPP/K. Pemerintah diharapkan dapat menindaklanjuti petugas-petugas khususnya petugas penagih yang meminta iuran lebih tinggi dari tarif yang ditetapkan kepada Para Wajib Retribusi. Apalagi petugas yang tidak memberikan karcis pada Wajib Retribusi yang sudah membayar iuran RPP/K.

\section{KESIMPULAN DAN SARAN}

\subsection{Kesimpulan}

Dalam perealisasiannya, ada beberapa ketidaksesuaian antara Perda No 3 Tahun 2011 atas Retribusi Pelayanan Persampahan/Kebersihan dengan penerapan tarifnya baik di Kecamatan Malalayang dan Kecamatan Sario, seperti beberapa rumah yang ditagih iuran Retribusi yang tidak sesuai dengan klasifikasi struktur, tidak adanya tanda bukti pembayaran seperti karcis retribusi, metode pembayaran iuran Retribusi Pelayanan Persampahan/Kebersihan yang berbeda-beda bahkan ada rumah-rumah yang sampahnya jarang diangkut oleh petugas.

\subsection{Saran}

Melakukan pendataan ulang bagi wajib Retribusi Pelayanan Persampahan/Kebersihan pada Kecamatan Malalayang dan Kecamatan Sario sehingga tidak ada lagi rumah masyarakat yang belum/tidak tersentuh Retribusi Pelayanan Persampahan/Kebersihan ini baik untuk kebersihan, keindahan dan kesejahteraan masyarakat maupun untuk penerimaan pendapatan Retribusi Pelayanan Persampahan/Kebersihan pada Kecamatan Malalayang dan Kecamatan Sario secara lebih menyeluruh 


\section{DAFTAR PUSTAKA}

Andy setiawan. 2016. Subjek Dan Objek Retribusi Daerah. http://tipsakuntansikeuangan.blogspot.co.id/2016/03/subjekdan-objek-retribusi-daerah.html? $m=1$

Belajar ekonomi. 2013. Akuntansi Perpajakan. http://www.ekonomi holic.com/2013/02/akuntansi-perpajakan.html? m=1

Christa Gloria Najoan. 2016. Analisis Sistem Pemungutan Dan Penyetoran Retribusi Pasar Pada Dinas Perindustrian Perdagangan Koperasi Dan Penanaman Modal Kota Kotamobagu. Skripsi. Fakultas Ekonomi dan Bisnis. Universitas Sam Ratulangi.

Damanhuri dan Padmi.2010. Pengelolaan Sampah. Skripsi. Program Studi Teknik Lingkungan Fakultas Teknik Sipil dan Lingkungan. Institut Teknologi Bandung.

Dessy Ayuni M. Toduho. 2014. Penerimaan Retribusi Pasar Dalam Upaya Meningkatkan Pendapatan Asli Daerah Kota Tidore Kepulauan. Fakultas Ekonomi dan Bisnis. Universitas Sam Ratulangi.

Ersita. 2016. Analisis Efektivitas Penerimaan Retribusi Daerah Dan Kontribusinya Terhadap Peningkatan Pendapatan Asli Daerah (PAD) Di Provinsi Sulawesi Utara. Skripsi. Universitas Sam Ratulangi

Hisamsam. 2017. "Akuntansi Pajak" Pengertian \& Fungsi-Tujuan-Teori-Peranan). http://www.dosenpendidikan.com/akuntansi-pajakpengertian-fungsi-tujuan-teori-peranan/

Jamil Talib. 2013. Factors Affecting The Acceptance Of Terminal Retribution At Mamuju District West Sulawesi Indonesia In The Era Of Regional Autonomy. Skripsi. STIE YPUP Makassar.

Lora Mona Mawikere. 2013. Analisis Sistem dan Prosedur Penerimaan Retribusi Kebersihan Daerah pada Dinas Pendapatan Daerah Kota Manado.Skripsi. Fakultas Ekonomi dan Bisnis. Universitas Sam Ratulangi.

Peraturan Daerah Nomor 7 Tahun 2006 Pengelolaan Persampahan dan Retribusi Kebersihan. Wahyudi. 2009. The Benefit Of Market Hygiene Retribution Collecting For Seller In Tugu Market Bandar Lampung 2009. Skripsi. Universitas Lampung.

Yuyus Yudistira. 2015. Revenue Potential Retribution. Skripsi. Universitas Padjadjaran.

Zurahniyah. 2016. Kontribusi Pemungutan Retribusi Kebersihan Terhadap Peningkatan Pendapatan Asli Daerah Kota Malang. Skripsi. Universitas STIKEN Jayanegara Malang. 